\title{
Metales Banskej Bystrice z roku 1820. Reambulácia juhozápadného úseku mestských hraníc spoločných so susedným teritóriom rodiny Radvanských
}

\author{
OTO TOMEČEK
}

\author{
Katedra histórie, Filozofická fakulta Univerzity Mateja Bela \\ $v$ Banskej Bystrici
}

Metales of the town Banská Bystrica from 1820. Perambulation of the southwest part of town borderline common with neighbouring domain of Radvanský family

Abstract: The paper deals with the analysis of a historical document which describes in detail the course of the perambulation of the borders of the town Banská Bystrica in 1820. The document named Metales consists of a text part and a map part. The text part is divided into seven chapters describing specific border sections. Through a detailed analysis of one of the border sections, the southwest part of town borderline common with neighbouring domain of Radvanský family we learn not only about the exact course of the borderline, but also about the location and owners of land near the borderline, participants of the perambulation and historical toponymy, as well as the form and location of border markers. The document captures the course of control of old border markers border piles (heaped soil or stones), border stones and border signs, as well as the making of new border markers.

Keywords: town Banská Bystrica, Radvanský family, domain, perambulation, borderline, border marker.

DOI: https://doi.org/10.24040/ahn.2021.24.02.112-133

Historické chotáre dedín a miest predstavovali ekonomickú základňu potrebnú pre sformovanie a neskôr aj každodennú existenciu obecných komunít v minulosti. Od obdobia stredoveku sa vytyčovaniu hraníc, ich označovaniu, spresňovaniu, kontrole a ochrane hraničných medzníkov venovala osobitná pozornost'. ${ }^{1}$ Výnimkou v tomto smere nebolo ani

\footnotetext{
Príspevok vznikol v rámci riešenia projektu Inovatívne sprístupnenie písomného dedičstva Slovenska prostredníctvom systému automatickej transkripcie historických rukopisov podporovaného Agentúrou na podporu výskumu a vývoja a evidovaného pod číslom APVV-19-0456.

1 Problematike vymedzovania hraníc majetkových celkov v stredoveku a ranom novoveku v priestore strednej Európy sa venovala už značná pozornost'. Vid' napr. práce: KARP, HansJürgen: Grenzen in Ostmitteleuropa während des Mittelalter : ein Beitrag zur Entstehungsgeschichte der Grenzlinie aus dem Grenzsaum. Köln; Wien : Böhlau Verlag, 1972. 184 s.; TAKÁCS, Lajos: Határjelek, határjárás a feudális kor végen Magyarországon. Budapest :
} 
mesto Banská Bystrica, ktorého hranice boli prvýkrát vymedzené vo výsadnej listine král'a Bela IV. v roku 1255.2 Priebeh spočiatku pomerne vol'ne vymedzenej hranice sa postupne spresňoval a označoval rôznymi spôsobmi priamo $v$ teréne. ${ }^{3}$

Vo výsadnej listine boli pre vytýčenie hraníc použité iba základné hraničné medzníky, medzi ktoré možno zaradit' prírodné krajinné prvky (vodné toky, sútok vodných tokov, ostrov, vrchy), ako aj prvky vzniknuté činnost'ou človeka (cesta). Neskôr, aby sa predchádzalo eventuálnym sporom, prípadne z dôvodu potreby presnejšieho vytýčenia hraničnej línie pre potreby hospodárskeho využívania prírodných daností chotára, začali pozdliž hranice vznikat' aj spresňovacie hraničné medzníky. Medzi najstaršie spomedzi nich môžeme zaradit' navŕšené kopy zeminy alebo kamenia, prípadne tiež znaky so symbolmi kríža vytesané do skál a vyryté do stromov. Najmladšiu, už novovekú, vrstvu spresňovacích hraničných medzníkov reprezentujú do skál a hraničných kameňov tesané litery a erby identifikujúce dedinu, mesto či majitel’a panstva. ${ }^{4}$ V prípade Banskej Bystrice

Akadémiai Kiadó, 1987. 227 s.; TYSZKA, Przemysław: 0 metodzie badań nad średniowiecznymi granicami lokalnymi. In: Kwartalnik Historii Kultury Materialnej, roč. 43, 1995, č. 4, s. 423-431; JANIŠ, Dalibor - ŠENKÝŘOVÁ, Jana: Hranice statků a pozemků - jejich zachycení v písemných (právních) pramenech. In: Archaeologia historica, roč. 29, 2004, s. 193-202; MARKOVÁ, Markéta: Vymezování hranic a jejich značení v př́rodě ve středověku. In: ŠIMŮNEK, Robert (ed.): Regiony - časoprostorové průsečníky? Praha : Historický ústav AV ČR, 2008, s. 98-106. Slovenské reálie sú obsiahnuté hlavne v prácach: LUKAČKA, Ján: Ohraničovanie majetkových celkov v stredoveku. In: Archaeologia historica, roč. 29, 2004, s. 61-65; MALINIAK, Pavol: „Meta ad modum crucis sculpta“ : Kríže na hraniciach majetkov vo Zvolenskej stolici. In: KOŽIAK, Rastislav - NEMEŠ, Jaroslav (eds.): Svätec a jeho funkcie v spoločnosti I. Bratislava : Chronos, 2006, s. 393-410; MALINIAK, Pavol: Človek a krajina Zvolenskej kotliny v stredoveku. Banská Bystrica : FHV UMB, 2009. 246 s.; MALINIAK, Pavol: The use of border signs in the Carpathian region : Contribution to the understanding of borders in the Middle and Early Modern Age. In: HOLEC, Roman - KOŽIAK, Rastislav (eds.): Historiography in Motion : Slovak Contributions to the 21st International Congress of Historical Sciences. Bratislava : Institute of History of SAS; Banská Bystrica : State Scientific Library, 2010, s. 62-76; HUDÁČEK, Pavol: Možnosti výskumu pôvodného prírodného prostredia v stredoveku (na príklade Šariša). In: Ingenii laus : Zborník štúdií venovaný jubilujúcemu prof. PhDr. Jánovi Lukačkovi, CSc. Bratislava : UK, 2017, s. 305-332; THURZO, Milan - JANČOVIČ, Pavol: Historické hraničné znaky a nápisy so zameraním na územie Bratislavy. Bratislava : Vydavatel'stvo UK, 2018. $266 \mathrm{~s}$.

2 MARSINA, Richard (ed.): Codex dipolomaticus et epistolaris Slovaciae II. Bratislava : Obzor, 1987, s. 341, č. 491.

${ }^{3}$ Vývoju hraníc mesta Banská Bystrica sa venujú štúdie: TOMEČEK, Oto: Vývoj hraníc chotára mesta Banská Bystrica od 13. do 19. storočia. In: Acta historica Neosoliensia 4. Banská Bystrica : FHV UMB, 2001, s. 163-174; TOMEČEK, Oto: Hranice mesta Banská Bystrica od roku 1255 do súčasnosti. In: Minulost' a prítomnost' Banskej Bystrice 1. Banská Bystrica : FHV UMB; ŠVK, 2006, s. 16-31.

${ }^{4}$ TOMEČEK, Oto: Spôsoby označovania hraníc vybraných miest a mestečiek stredného Slovenska od 13. do polovice 19. storočia. In: VALO, Ján (ed.): Mesto a jeho historická krajina : Zborník príspevkov z rovnomennej konferencie. Bratislava : UK, 2020, s. 28-47. 
to boli majuskulné litery $\mathrm{CN}$ a zjednodušený erb mesta, ${ }^{5}$ ktorý mal podobu 3-krát deleného štítu so 4 pozdížnymi pruhmi. ${ }^{6}$

Už od stredoveku boli hranice Banskej Bystrice stabilné a zásadnejšie sa nemenili. Ešte v stredoveku v historickom chotári mesta vzniklo niekol'ko sídel. Tie v novoveku doplnili d’alšie, hlavne vo vyšších polohách ležiace drevorubačské a uhliarske osady patriace pod jurisdikciu Banskej komory v Banskej Bystrici. Práve zvýšená hospodárska aktivita banskej komory v priestore donovalského sedla $\mathrm{v}$ druhej polovici 18 . a na začiatku 19. storočia destabilizovala severovýchodné hranice mestského chotára v tomto geografickom priestore. Hranice mesta, ktoré boli na tomto úseku totožné so stoličnými hranicami, boli preto $\mathrm{v}$ danom období brané ako sporné. ${ }^{7}$

Od čias, kedy došlo k podrobnému vymedzeniu a označeniu hraničnej línie prostredníctvom rozličných hraničných medzníkov a znakov, bolo potrebné ich stav pravidelne kontrolovat'. Obchádzanie hraníc vybranými členmi obecnej komunity malo upevnit' povedomie o dôležitosti ochrany vlastného teritória. Išlo tu zároveň o formovanie akejsi kolektívnej historickej pamäte. Okrem starších zástupcov mesta, od ktorých sa očakávali vedomosti ohl'adom umiestnenia medzníkov a priebehu hraníc, sa museli obchôdzky zúčastňovat' aj mladší mešt'ania či dokonca deti mešt'anov. Práve oni mali zabezpečit' udržanie vedomostí o hraniciach do blízkej aj vzdialenejšej budúcnosti. ${ }^{8}$ Obchôdzky hraníc boli väčšinou

\footnotetext{
5 Originálny erb Banskej Bystrice vychádzajúci z arpádovského královského erbu mal osem, alebo niekedy tiež devät', vo farebnom vyhotovení červených a bielych pozdížnych brvien, resp. pruhov. Poznáme však aj prípady použitia jeho redukovanej podoby ako napríklad na rukoväti popravného meča, alebo na mestskej zástave z roku 1722, ktoré môžeme nájst' v zbierkach Stredoslovenského múzea v Banskej Bystrici.

${ }^{6}$ Spomedzi všetkých doposial' zdokumentovaných erbových hraničných znakov mesta Banská Bystrica sa podarilo zatial' len v jednom prípade identifikovat' typologicky odlišný hraničný znak Banskej Bystrice s vyobrazením 4-krát deleného a na pät' pozdĺžnych pruhov zredukovaného erbu. Tento hraničný znak je vytesaný na brale medzi Královou studňou a Smrekovicou na severozápadnom úseku mestských hraníc spoločných s panstvom rodiny Révaiovcov.

${ }^{7}$ Rozširovaním územia určeného na t’ažbu dreva smerom do Liptova boli v rokoch 1753 a 1809 vytýčené demarkačné línie Banskej komory v Banskej Bystrici. Počas tohto obdobia zrejme došlo k narušeniu integrity pôvodných hraníc a zároveň aj strate povedomia o jej pôvodnom vymedzení. $V$ tomto prípade však nemožno vylúčit' ani starší pôvod hraničných sporov v tejto oblasti, ked’že osady Mistríky a Mišúty založené v prvej polovici 17. storočia ležali na opačnej strane donovalského sedla ako ostatné tu založené uhliarske osady. Bližšie k tejto problematike pozri: TOMEČEK, Oto: Drevorubači a uhliari v lesoch Banskej Bystrice : K problematike osídlenia horských oblastí banskobystrického chotára do polovice 19. storočia. Banská Bystrica : FHV UMB, 2010, s. 19-21.

${ }^{8}$ V niektorých prípadoch nebolo zriedkavým javom ani praktizovanie obradu tzv. pamätných výpraskov, ktoré mali dopomôct' k lepšiemu zapamätaniu si miesta, na ktorom k danej udalosti došlo. Podobný význam mali aj pohostenia priamo pri dôležitých hraničných medzníkoch, najčastejšie pri trojhraničných bodoch. Porov.: ŠLÉZAR, Pavel: Sády, kopy a
} 
spojené aj s pohostením na náklady iniciátora obchôdzky. V prípade sporov hradili výdavky sporné strany. $V$ prípade pravidelných kontrolných obchôdzok mestských hraníc platilo všetky výdavky mesto. ${ }^{9}$

Na základe starých zvykov mali obyvatelia Banskej Bystrice právo a zároveň aj povinnost' poznat' hranice svojho mesta. Vybraní členovia mestskej rady spolu s vybranými mešt'anmi a ich det'mi preto vždy po istom čase obchádzali na koňoch či pešo hranice mesta. 0 svojich zisteniach podávali správy, v ktorých zvykli urgovat' opravy poškodených hraničných kameňov. ${ }^{10}$ Historický chotár Banskej Bystrice patril svojou rozlohou prevyšujúcou $200 \mathrm{~km}^{2} \mathrm{k}$ tým najrozsiahlejším na Slovensku. Matej Bel vo svojom diele uviedol, že hranice mesta boli také rozsiahle, že aj jazdcovi na koni trvalo takmer tri dni, kým ich dokázal celé obíst'. ${ }^{11}$

V letných mesiacoch, od 1. augusta do 19. septembra, v roku 1820 mesto Banská Bystrica uskutočnilo reambuláciu hraníc svojho historického chotára. Jej základom bola dôkladná obchôdzka jednotlivých hraničných úsekov spojená so zist'ovaním, overovaním a vymeriavaním priebehu hraničnej línie. Jej priebeh aj so všetkými zmenami bol následne zaznamenaný v knihe Metales, ktorej súčast’ou je textová aj mapová čast'. ${ }^{2}$ Čistopis dokumentu prečítal a overil prísažný prvý podnotár Zvolenskej stolice Ludovít Radvanský (Ludovicus de Radvány). ${ }^{13}$ Zápis

\footnotetext{
„výprask na pamětnou“ : Hranice ve středověké krajině Drahanské vrchoviny. In: Vlastivědný věstník moravský, roč. LIX, 2007, č. 2, s. 155-156.

${ }^{9} \mathrm{~V}$ účtovnej knihe mesta sa z roku 1556 zachovali údaje o finančných výdavkoch spojených s konzumáciou jedla a nápojov počas obhliadky mestských hraníc. Podl'a nich vieme, že sa platilo za konzumáciu rýb (rybie rezne, kapry a šobské ryby), kureniec, husí, chleba, octu a vína. Osobitný poplatok bol uhradený aj kuchárom, ktorí stravu pripravili. Podl'a: JURKOVICH, Emil: Dejiny král'ovského mesta Banská Bystrica. Preložil Imrich NAGY. Banská Bystrica : Pribicer, 2005, s. 194.

10 JURKOVICH, Dejiny král'ovského mesta Banská Bystrica, s. 194.

${ }^{11}$ BEL, Matej: Zvolenská stolica. NAGY, Imrich - TURÓCI, Martin (eds.). Čadca : Kysucké múzeum, 2017, s. 201.

${ }^{12}$ Slovenský národný archív, špecializované pracovisko Slovenský banský archív v Banskej Štiavnici (d’alej SNA - SBA BŠ), fond Banská komora v Banskej Bystrici, inv. č. 90. Ide o latinsky písaný dokument v zviazanej polokoženej väzbe s rozmermi 26 x $41 \mathrm{~cm}$. Pôvodný dokument bol vyhotovený bez paginácie. Súčasná chybná paginácia bola vytvorená dodatočne pri archívnej evidencii dokumentu. Podla nej má kniha 244 strán. V skutočnosti má dokument 254 strán. Chybná paginácia začína na strane 40, ktorá je označená dvakrát, naopak strana 83 chýba. Po strane 165 nasleduje strana 156, takže strany 156 až 165 sú chybne zdvojené. Podobne dvakrát je očíslovaná aj strana 237.

${ }^{13}$ L’udovít (II.) Radvanský (1785 - 1847) zastával post prvého podnotára Zvolenskej stolice nepretržite 18 rokov v rokoch 1809 - 1827. V správe Zvolenskej stolice začínal v roku 1808, kedy bol menovaný za druhého podnotára. Neskôr jeho kariéra výrazne napredovala. V rokoch 1827 - 1832 zastával post riadneho (hlavného) stoličného notára a v rokoch 1832 - 1836 zastával najvyššiu volenú funkciu v stoličnej samospráve, post riadneho (prvého) podžupana. Na vrchole svojej kariéry bol menovaný do čestnej funkcie cisársko král'ovského radcu a pasovaný za Rytiera Zlatej ostrohy. Podl'a: JANURA, Tomáš: Úradníci
} 
o tom bol urobený na generálnej kongregácii Zvolenskej stolice, ktorá zasadala 1. októbra v roku 1823 v Banskej Bystrici.

Textová čast' Metales je rozdelená na sedem častí, ktoré zodpovedajú jednotlivým hraničným úsekom. Prvý úsek, ktorému venujeme detailnejšiu pozornost' $\mathrm{v}$ d'alšej časti tejto štúdie, zaznamenáva juhozápadný úsek mestských hraníc spoločných so susedným teritóriom rodiny Radvanských, na základe reambulácie vykonanej v dňoch 1. - 4. augusta a 19. septembra 1820. Druhý úsek popisuje priebeh západných hraníc mesta, spoločných s mestom Kremnica, na základe reambulácie vykonanej v dňoch 9. - 14. augusta 1820. Tretí, severozápadný, úsek mestských hraníc predstavuje spoločné hranice mesta s rodinou Révaiovcov, na základe reambulácie vykonanej 16. - 19. augusta 1820. Štvrtý úsek popisuje priebeh severných hraníc mesta, spoločných s Likavským panstvom, podl'a reambulácie z 21. - 24. augusta 1820. V piatej časti je zaznamenaný východný úsek mestských hraníc, spoločných s L’upčianskym panstvom, na základe reambulácie vykonanej v dňoch 28. - 29. augusta a 12. septembra 1820. Šiesty úsek predstavuje prvú čast' južného úseku, na ktorom mesto susedí s územím dediny Mičiná patriacej rodine Benických (podl'a reambulácie z 13. - 15. septembra 1820). Posledný úsek napokon popisuje priebeh druhej časti južných hraníc mesta, spoločných s komposesorátnym územím Iliaš, na základe reambulácie vykonanej v dňoch 16. - 18. septembra 1820. Predmetom reambulácie sa nestal jedine vyššie zmienený sporný severovýchodný úsek mestských hraníc, spoločných s Likavským panstvom.

Za textovými opismi jednotlivých hraničných úsekov sa nachádzajú mapy príslušných úsekov. Všetky mapy vyhotovil ešte v roku 1820 riadny geometer Zvolenskej stolice Juraj Mihalko (Georgius Mihalko). ${ }^{14}$ Tak ako rembulácia mestského chotára bola rozdelená na sedem hraničných úsekov, zostavil aj Mihalko sedem máp. ${ }^{15}$ Napriek zhodnému počtu

Zvolenskej stolice v rokoch 1790 - 1848. In: KOVÁČ, Dušan - KOWALSKÁ, Eva - ŠOLTÉS, Peter a i.: Spoločnost' na Slovensku v dlhom 19. storočí. Bratislava : Veda, 2015, s. 106, 107 a 119; JANURA, Tomáš - FILLOVÁ, Lubica - ŠIMKOVIC, Michal: Vidiecke šl'achtické sídla v Zvolenskej stolici. B. m. : Spoločnost' Kolomana Sokola, 2016, s. 38; SZLUHA, Márton: Felvidéki nemes családok I - II. (Árva, Trencsén, Zólyom, Sáros, Turóc). [CD-ROM]. Budapest : Arcanum, 2007.

${ }^{14}$ Inštitút stoličného geometra (zememerača) existoval vo Zvolenskej stolici už v druhej polovici 18. storočia. Dôležitou náplňou jeho práce bolo práve vyhotovovanie hraničných máp, ked’že riešenie hraničných sporov patrilo práve do kompetencie stoličných orgánov. Napríklad v roku 1791 zastával úrad geometra Zvolenskej stolice Augustín Petráš (Petrasch), ktorý v tomto roku vyhotovil mapu spoločnej hranice medzi mestom Lubietová a panstvom L'upča. Pozri: Štátny archív v Banskej Bystrici (d’alej ŠA BB), fond Lubietová, slobodné král'ovské mesto (1282 - 1885), inv. č. 1152, 1-a.

${ }^{15}$ Niektoré z týchto máp, vzniknutých pri príležitosti reambulácie, boli neskôr pri rôznych príležitostiach kopírované inými kartografmi. Napríklad kópiu mapy znázorňujúcej prvý úsek spoločnej hranice Banskej Bystrice s L’upčianskym komorským hradným panstvom 
hraničných úsekov a máp, jednotlivé mapy úplne nezodpovedali reambulovaným hraničným úsekom. K prvým štyrom úsekom (juhozápadný, západný, severozápadný a severný) vytvoril príslušné mapy presne v súlade s popísanými úsekmi. Dlhý východný hraničný úsek susediaci s L’upčianskym panstvom však už namiesto jednej mapy znázornil na dvoch mapách. Naopak, posledné dva kratšie hraničné úseky prechádzajúce cez Bystrickú vrchovinu, na ktorých mesto susedilo s dedinami Mičiná a Iliaš, Mihalko znázornil iba na jednej mape.

Počas samotnej obchôdzky jednotlivých hraničných úsekov Mihalko vykonával meračské práce. Pri nich meral uhly v stupňoch (Directio acus Magnetica Gradus) a vzdialenosti vo viedenských siahach (Distantia in Orgiis Viennensibus) medzi jednotlivými v teréne označenými hraničnými medzníkmi. ${ }^{16}$ Uhly sa merali pomocou kompasu, resp. buzoly. $\mathrm{Na}$ meranie vzdialeností sa v tomto čase zvykli používat' drevené laty s dížkou jednej viedenskej siahy, alebo meračské ret’aze, povrazy či tkaninové pásma. $V$ prípade použitia povrazu a pásma boli potrebné aj dve palice k ich napnutiu. Nevyhnutné boli tiež výtyčky a drevené kolíky, papier, pravítko a písací prostriedok. ${ }^{17} \mathrm{Na}$ základe týchto meračských prác uskutočnených priamo v teréne mohol vytvorit’ finálne kartografické výstupy. Tieto vznikali neskôr počas kancelárskych prác, pri ktorých bol finalizovaný samotný mapový nákres, doplnili sa písomné a číselné popisy, mapa sa kolorovala (v tomto prípade hlavne hraničná línia),18 dokreslila sa mierka mapy, línia smeru poludníku (Linea Meridionalis) a línia označujúca magnetický sever (Linea Magnetica). Na samotnom konci kartografických prác bola každá mapa označená pečat'ou geometra otlačenou do červeného vosku, ktorá potvrdzovala správnost’ mapového výstupu.

Okrem stoličného geometra, ktorý vykonával najdôležitejšie práce v súvislosti s hraničnou reambuláciou, sa aktu obhliadky mestských hraníc zúčastnilo aj vel'ké množstvo svedkov pochádzajúcich z miest a dedín ležiacich po oboch stranách hranice. Dotknutého juhozápadného úseku

vyhotovil v roku 1824 pomocník komorského geometra Jozef Fischer. SNA - SBA BŠ, fond Hlavný komorskogrófsky úrad V, inv. č. 13 098, celá mapa bola publikovaná v práci: HOMOLA, Vladimír - TOMEČEK, Oto (eds.): Hrad L'upča : Klenot Pohronia vo svetle vekov. Podbrezová : Železiarne Podbrezová, a. s., 2017, s. 116-117.

16 Viedenská, tiež Dolnorakúska, siaha (lat. orgia, nem. Klafter) sa v našich krajinách používala ako oficiálna dížková miera od čias panovania Márie Terézie až do zavedenia metrickej sústavy v 70. rokoch 19. storočia. Jedna siaha zodpovedala dížke 1,896 m.

17 Uvedené spôsoby merania vzdialeností sa používali pri vymeriavaní jozefínskeho katastru. Vid': BUMBA, Jan: České katastry od 11. do 21. století. Praha : Grada, 2007, s. 42.

${ }^{18} \mathrm{Na}$ všetkých mapách bola kolorovaná hraničná línia, ktorá bola na niektorých mapách označená len červenou farbou, inde bola použitá farebná dvojlinka kombinujúca červenú farbu so žltou alebo zelenou farbou. Červenou farbou boli vyznačené aj niektoré stavby postavené v blízkosti hraničnej línie. Zrejme išlo o tie stavby, ktoré boli postavené z pevného stavebného materiálu (kameň, tehla). 
mestských hraníc, na ktorom Banská Bystrica susedila s územím patriacim rodine Radvanských, sa okrem zmieneného geometra zúčastnilo až 111 osôb. Medzi týmito účastníkmi sa, pochopitel'ne, nachádzali aj zemskí páni a ich zástupcovia, ale aj úradníci Zvolenskej stolice a Banskej komory v Banskej Bystrici. Všetci zúčastnení vystupovali v pozícii svedkov, ktorí mali potvrdit' správnost' ohraničenia a umiestnenia jednotlivých hraničných medzníkov a znakov. Starší svedkovia mali potvrdit’ oprávnenost' umiestnenia týchto medzníkov a znakov v porovnaní s minulým stavom, ked'že je možné predpokladat', že už v minulosti sa podobnej obchôdzky hraníc zúčastnili. Mladší svedkovia, vrátane detí od 10 do 18 rokov, boli naopak prizvaní z toho dôvodu, aby si zapamätali polohu týchto hraničných bodov do budúcnosti.

Priamo z Banskej Bystrice sa obchádzania dotknutého hraničného úseku zúčastnilo 43 osôb. Medzi nimi nachádzame piatich členov mestskej rady (magistratus resp. senatus) - senátorov, podnotára, fiškála, účtovníka, pokladníka či prvého pisára. Volenú obec mesta (electa communitas) zastupoval tribún l'udu a jej d'alší piati členovia. ${ }^{19}$ Zvyšok predstavovali radoví meštania, z ktorých niektorí sa hraničnej obchôdzky zúčastnili aj so svojimi synmi. Medzi nimi možno uviest' napríklad známeho banskobystrického zlatníka Samuela Libaya (1782 - 1866), s ktorým sa obchôdzky zúčastnil aj jeho najstarší syn Gustáv. ${ }^{20}$ Práve on bol najmladším priamym účastníkom aktu reambulácie tohto úseku mestských hraníc. Okrem neho evidujeme pri obhliadke tohto úseku d'alších sedem Banskobystričanov v nižšom veku ako 18 rokov. Zástupcovia mesta napokon k obhliadke pribrali aj murárskeho predáka (murariorum pallirio) Mateja Stogla, ${ }^{21}$ ktorý mal na starosti vytesanie nových hraničných znakov.

Banskú Bystricu zastupovali na obhliadke aj vybraní obyvatelia niektorých poddanských dedín mesta. Z dediny Harmanec (ex villa Harma-

\footnotetext{
${ }^{19}$ Tribún l’udu stál pôvodne na čele 24-člennej vonkajšej mestskej rady. Od konca 18. storočia, po zlúčení vonkajšej rady a volenej obce, stál na čele volenej obce. Bol akýmsi prostredníkom medzi ňou a senátom. Medzi jeho d'alšie funkcie patrila tiež kontrola mestskej pokladnice a starostlivost' o ochranu mestských privilégií, práv a záujmov. Porovnaj: MARKOV, Jozef: Odraz politických zápasov v obecnej správe Banskej Bystrice v 16. - 19. storočí. Bratislava : Vydavatel'stvo SAV, 1973, s. 112-113.

20 Ten mal mat' podl'a zápisu v tom čase 10 rokov.V skutočnosti sa Gustáv Teofil Libay narodil 4. júna 1812, takže v čase konania reambulácie mal len 8 rokov. Porovnaj GLOCKO, Filip: Samuel Libay : život a dielo banskobystrického zlatníka. Banská Bystrica : Stredoslovenské múzeum, 2018, s. 44.

${ }^{21}$ Slovo pallirio predstavuje latinizovanú formu slova palier, ktoré označuje predáka alebo vedúceho murárskych prác. Ekvivalentom je nemecký Polier, mad’arský pallér, či v češtine paliŕr.

Uvedený Matej Stogl sa zúčastnil aj reambulácie severnej hranice mesta spoločnej s Likavským panstvom. Označenie západnej hranice mesta spoločnej s mestom Kremnica a severozápadnej hranice mesta spoločnej s panstvom Révaiovcov dostal za úlohu kamenársky majster Leonard Horn. Pri ostatných úsekoch sa mená tvorcov hraničných znakov priamo neuvádzajú.
} 
netz) ležiacej na území mesta to bolo dvanást' mestských zamestnancov. ${ }^{22}$ Dvaja d’alší svedkovia zastupujúci mesto pochádzali z Kostiviarskej a jeden z dediny Sv. Jakub.

Úradnícky aparát banskobystrickej banskej komory zastupovalo pät' osôb, medzi ktorými boli fiškál so svojim adjunktom, provízor, lesmajster a lesný praktikant. Post banskobystrického banskokomorského lesmajstra v tom čase zastával Jozef Dekret (1774 - 1841), priekopník moderného lesohospodárstva v našich krajinách. ${ }^{23}$ Banskú komoru v Banskej Bystrici napokon na obchôdzke zastupovali aj dvaja komorskí poddaní pochádzajúci z dedín Majer a Kostiviarska.

Rodinu Radvanských, ako feudálneho pána na teritóriu susediaceho s mestom, zastupovali tri osoby. Tou najvýznamnejšou spomedzi nich bol zastupujúci (druhý) podžupan Zvolenskej stolice Anton Radvanský (1769 - 1840).24 Ďalším zúčastneným členom rodiny bol Karol Radvanský. ${ }^{25}$ Napokon, Evu Prónay, ${ }^{26}$ vdovu po zosnulom král'ovskom radcovi Jánovi Radvanskom, ${ }^{27}$ zastupoval jej provízor František Banko.

${ }^{22}$ Pod dedinou Harmanec možno v skutočnosti rozumiet' pravdepodobne dve sídla, teda Dolný a Horný Harmanec.

${ }^{23}$ Post komorského lesmajstra zastával v rokoch 1814 - 1837. Vo svojej funkcii presadzoval hospodárnu t'ažbu dreva, umelé zalesňovanie a pestovanie lesa, zdokonalenie evidencie a ochrany lesa, zlepšenie sociálneho postavenia lesného robotníctva. Práve jeho zásluhou sa podarilo v celej oblasti presadit' zavedenie ručnej píly namiesto sekery pri stínaní stromov. Bližšie k uvedenej osobnosti napr.: ŠŤASTNÝ, Tibor: Dekretov boj o zastavenie devastácie lesov a o ich ciel'avedomú ochranu. In: JANČ́́K, Alojz (ed.): Jozef Dekret Matejovie. Bratislava : ŠPN, 1954, s. 85-196; ŠŤASTNÝ, Tibor: Ako povzniesol Dekret lesné hospodárstvo. In: JANČÍK, Alojz (ed.): Jozef Dekret Matejovie. Bratislava : ŠPN, 1954, s. 239-243; ŠŤASTNÝ, Tibor: Jozef Dekret-Matejovie. In: TIBENSKÝ, Ján (ed.): Priekopníci vedy a techniky na Slovensku 2. Bratislava : Obzor, 1988, s. 196-200; STOCKMANN, Viliam: Historické lesnícke osobnosti. Banská Bystrica; Malinovo : Lesy SR, š. p., 2012, s. 47.

${ }^{24}$ Anton (I.) Radvanský zastával volený post zastupujúceho (druhého) podžupana 16 rokov od roku 1811 do roku 1827. V stoličnej správe začínal ako podslúžny $(1801$ - 1807) a následne slúžny horného okresu (1807 - 1811). Neskôr, v rokoch 1827 - 1832, zastával pozíciu riadneho (prvého) podžupana Zvolenskej stolice. Niekedy v tomto období bol tiež menovaný za cisársko-král'ovského radcu. Podl'a: JANURA, Úradníci Zvolenskej stolice v rokoch 1790 1848, s. 104 a 119; JANURA - FILLOVÁ - ŠIMKOVIC, Vidiecke šlachtické sídla v Zvolenskej stolici, s. 50-51; SZLUHA, Felvidéki nemes családok.

${ }^{25}$ Mohlo tu íst' o menej významného člena rodu, syna Petra (IV.) Radvanského a Eufrozíny (Fruzsiny) Czipser, ktorý sa podl'a Mártona Szluhu narodil 14.1.1764. Pozri: SZLUHA, Felvidéki nemes családok. Podl’a zápisu vo zvolenskej matrike však bol Karol L’udovít Radvanský pokrstený už o niekol'ko dní skôr, dňa 10.1.1764. ŠA BB, Zbierka matrík, Matrika krstených r. k. farského úradu vo Zvolene 1758 - 1840. Podl'a: www.familysearch.org [2021-08-04].

${ }^{26}$ Eva Prónay (Pronay) bola príslušníčkou šl'achtického rodu zo Slovenského Pravna a Blatnice. Narodila sa v roku 1747, takže v čase reambulácie hraníc mala už 73 rokov. SZLUHA, Felvidéki nemes családok.

27 Ján (V.) Radvanský (1739 - 1815), otec Antona (I.) Radvanského, bol taktiež významným stoličným úradníkom. Najprv zastával post stoličného pokladníka, neskôr bol zastupujúcim podžupanom. Počas jozefínskych reforiem zastával post riadneho podžupana spojenej 
Z mestečka Radvaň sa obhliadky zúčastnilo 31 miestnych obyvatel’ov, medzi ktorými nachádzame tunajšieho notára Juraja Markoviča, hajtmana Jána Furdíka a lesníka Radvanského panstva Daniela Moska. ${ }^{28}$ Spomedzi zúčastnených obyvatel'ov Radvane možno deviatich označit' za mladistvých. Takmer všetkých ich možno stotožnit' zo synmi zúčastnených dospelých obyvatel'ov Radvane. ${ }^{29}$ Stranu Radvanských napokon zastupovalo aj dvanást' poddaných z dediny Skubín, medzi ktorými nachádzame aj miestneho richtára Jána Bukovského. Dvaja Skubínčania boli mladiství chlapci vo veku 14 a 16 rokov, ktorí sa obhliadky zúčastnili bez svojich otcov.

Už od stredoveku bol juhozápadný úsek mestských hraníc, spoločný s teritóriom rodiny Radvanských, pomerne stabilný a aj napriek početným sporom medzi oboma stranami sa ho nedotkli zásadnejšie zmeny. ${ }^{30}$ Od sútoku rieky Hron s potokom Udurna (v súčasnosti Radvanský potok) postupovala hranica proti prúdu toku Udurny. Od neho potom prechádzala k ceste do Turca a d'alej pokračovala nahor tokom Tajovského potoka až na hlavný hrebeň Kremnických vrchov. Reambulácia z roku 1820 zaznamená v knihe Metales umožňuje priebeh tejto približne 12 km dlhej hraničnej línie ešte viac spresnit'.

Obchôdzka spojená s vymeriavaním hraníc na tomto úseku začala 1. augusta 1820 na sútoku Hrona s Udurnou. Odtial'to komisia postupovala niekol'ko nasledujúcich dní proti prúdu Udurny a Tajovského potoka smerom nahor až na hlavný hrebeň Kremnických vrchov, k trojhraničnému bodu rozdel'ujúcemu chotáre Banskej Bystrice, Radvanského panstva a Kremnice. Ked’že sa postupovalo proti prúdu oboch potokov, tak územie vpravo od hraničnej línie komisia označovala ako banskobystrické a územie vl'avo ako radvanské. ${ }^{31}$

Na spodnom toku Udurny prechádzala hranica popri komorskom uhlisku na banskobystrickej strane až k drevenému mostu nad Udurnou, ${ }^{32}$

\footnotetext{
Turčiansko-Zvolenskej stolice. Okrem čestnej funkcie cisársko-král'ovského radcu bol pasovaný na Rytiera Zlatej ostrohy. Zomrel 10. apríla 1815 v Radvani. JANURA - FILLOVÁ - ŠIMKOVIC, Vidiecke šl'achtické sídla v Zvolenskej stolici, s. 50; SZLUHA, Felvidéki nemes családok. ${ }^{28}$ Ján Furdík bol v zozname účastníkov zapísaný ako ductor oppidi. Predpokladáme, že ide o tú istú osobu, ktorá zastávala v roku 1820 funkciu tunajšieho hajtmana, niekedy nazývaného tiež kapitánom. FURDÍKOVÁ, Eva: Správa mestečka Radvaň v 17. - 19. storočí. In: SKLENKA, Vladimír - PECNÍK, Marcel a i.: Radvaň : monografia mestečka. Banská Bystrica : Centrum pre rozvoj cestovného ruchu, b. r., s. 117.

${ }^{29}$ Medzi dospelými nenachádzame iba priezvisko mladistvého Jána Matrošoviča.

30 TOMEČEK, Hranice mesta ..., s. 30.

${ }^{31} \mathrm{~V}$ súčasnej geografickej terminológii sa naopak strany odvodzujú od smeru vodného toku. 32 Išlo o dolné uhlisko ležiace v blízkosti dolných hrablí slúžiacich na zachytávanie dreva plaveného po Hrone. Drevným uhlím vyrobeným na tomto uhlisku bol zásobovaný hutnícky komplex postavený v 16. storočí, ktorý stál v jeho tesnej blízkosti na sútoku Tajovského potoka s Hronom.
} 
ktorý bol postavený na ceste smerujúcej z Banskej Bystrice do dolnej časti mestečka Radvaň. Ďalej za mostom vpravo stál dom komorského uhliarskeho pisára s prislúchajúcou záhradou siahajúcou až ku korytu Udurny. Na ňu nadväzovala d'alšia záhrada pána Karola Fluka a záhrady Stelleviánska a Karola Margarovského (hortus Stellevianus et Caroli Margarovszky). ${ }^{33}$ Za týmito záhradami sa nachádzal d'alší drevený most cez Udurnu na ceste z Banskej Bystrice cez hornú Radvaň do Kremničky. Na opačnej radvanskej strane sa oproti uhlisku a spomínaným záhradám nachádzali pozemky radvanského intravilánu. Ďalej za týmto druhým mostom, priamo pri hraničnom toku Udurny, stála krčma banskobystrického mešt’ana Michala Páleša s pril'ahlou záhradou. ${ }^{34} \mathrm{Za}$ ňou pokračovalo Pálešove pole, za ktorým nasledovala lúka d'alšieho banskobystrického mešt'ana Samuela Sumráka. Oproti týmto pozemkom na opačnom brehu Udurny ležalo pole pána L'udovíta Radvanského, za ktorým sa začínala záhrada obyvatel’a Radvane Daniela Krušpána. Tieto pozemky sa tiahli po oboch stranách hranice až k miestu, kde sa do Udurny vlieval potok Motičina.

Od uvedeného sútoku až po cestu do Skubína viedla hranica popri pokračujúcich pozemkoch Samuela Sumráka a banskobystrického radného Jána Fluka ležiacich na pravej, teda banskobystrickej strane. ${ }^{35} \mathrm{Na}$ opačnej, radvanskej strane ležali pri hranici pole Jána Ondričina, poddaného Karola Radvanského, za ktorým nasledovali panská lúka Radvanských a polia pána Imricha a L'udovíta Radvanského. Pod oboma menovanými pol’ami sa nachádzali dva vodné pramene tvoriace hraničné medzníky. Na tomto úseku hranice sa už spomínajú aj prvé spresňovacie hraničné medzníky tvorené kamennými kopami a hraničnými kameňmi označenými štítom (erbom) mesta. V blízkosti jedného z prameňov bola vytvorená dočasná hraničná kopa (intermialis cumulus), ktorá mala byt' hned' po skončení raembulácie nahradená alebo doplnená označeným hraničným kameňom. Na mieste, kde sa hraničná línia približovala k ceste do Skubína, komisia zaznamenala aj existenciu prvých hraničných kameňov zrejme už so skôr vytesanými hraničnými znakmi mesta.

\footnotetext{
${ }^{33}$ Fluckovci boli vplyvný šl'achtický rod pôvodom z Čiech žijúci v Banskej Bystrici. Pôsobili najmä ako úradníci a zamestnanci v službách tunajšej banskej komory. Postupne prenikli aj do úradníckeho aparátu Zvolenskej stolice. JANURA, Úradníci Zvolenskej stolice v rokoch 1790 - 1848, s. 127.

V prípade hortus Stellevianus by pravdepodobne mohlo íst' skôr o hortus Stellerianus, odvodené od bežného priezviska Steller.

${ }^{34}$ Mešt'an Michal Páleš (Palesch) sa ako člen volenej obce osobne zúčastnil reambulačnej obhliadky hraníc ako zástupca mesta.

35 Ján Fluk (Fluck) sa ako člen mestskej rady osobne zúčastnil reambulačnej obhliadky hraníc ako zástupca mesta.
} 
Od cesty do Skubína hranica schádzala z víšku nižšie, popri poliach Karola Fluka z jednej strany a Radvanských z druhej strany, k inej ceste vedúcej do Skubína a Podlavíc. Popri nej potom hranica postupovala až k dedinám Podlavice a Skubín. Napravo prechádzala hranica popri poli mešt'ana Schuberta a poliach podlavických poddaných mesta, menovite istého Drobu. ${ }^{36}$ Vl'avo ležali polia Radvanských a sedliakov zo Skubína, ktoré sa tiahli až na kopčeky zvané Holé Hôrky (Holje Huorky). Na dva kamene stojace vedl'a cesty nechali predstavitelia mesta vytesat' hraničný znak so štítom mesta. Ďalej pred domom zmieneného Drobu komisia objavila starý hraničný kameň, na ktorom už bol vytesaný znak mesta. Pri tejto príležitosti ho nechali pevnejšie osadit' do zeme. Za záhradou tohto domu našli ešte starý vel'ký mlynský kameň zakopaný $\mathrm{v}$ zemi, ktorý už bol rovnako označený štítom mesta.

Od dedín Podlavice a Skubín, ktoré od seba oddel'oval Tajovský potok, postupovala hranica d'alej takmer po celý čas korytom tohto vodného toku až do jeho pramennej oblasti. ${ }^{37}$ Obhliadka hraníc reambulačnou komisiou pokračovala popri Podlavickom mlyne. K d'alšiemu Skubínskemu mlynu rodiny Radvanských, ${ }^{38}$ pri ktorom sa nachádzal aj most cez Tajovský potok, prišla komisia až nasledujúceho dňa (2. augusta). Odtial' pokračovala popri vyústení doliny Hlboká na l'avej strane až k dedinám Tajov a Jabríková, z ktorých prvá ležala na pravom banskobystrickom brehu potoka a druhá na jeho l'avom radvanskom brehu. Tu sa vymeraná hranica čiastočne odchýlila od potoka a pokračovala po ceste naprieč Tajovom. Cesta tu prechádzala tesne okolo mlynského kanála, na ktorom stál komorský mlyn, a tiež okolo domov komorských robotníkov na opačnej strane cesty. Ďalej vl'avo od cesty, hned' pri potoku, stála pražiareň so starou hutou, nad ktorou bol murovaný most vedúci k novej hute. Ešte d'alej po oboch stranách cesty stáli viaceré domy komorských robotníkov. $\mathrm{O}$ niečo d'alej na pravej strane cesty stála farská budova. Za ňou bol postavený d'alší murovaný most cez Tajovský potok, v blízkosti ktorého sa do Tajovského potoka vlieval Kordícky potok (Kordikiensis rivus). Napravo, hned' za mostom sa nachádzal dom komorského hutného prefekta. Ďalej cestou cez Jabríkovú s domami po oboch stranách prichádzala hranica k drevenému mostu na Tajovskom potoku.

\footnotetext{
${ }^{36}$ Matričné záznamy dokladajú v Podlaviciach pomerne početné zastúpenie priezviska Droba. Medzi Drobovcami tu nachádzame napríklad aj mlynára Štefana Drobu, doloženého v rokoch 1793 - 1806. Podl'a: www.familysearch.org [2021-08-07].

${ }^{37} \mathrm{Na}$ mapovom liste 2. vojenského mapovania z roku 1845 je Tajovský potok pomenovaný ako Hotarska Woda. Österrechisches Staatsarchiv - Kriegsarchiv (d'alej ÖStA - KA), Franziszeische Landesaufnahme, Section 39 - Colonne XXXII.

38 Ako Skubínsky je mlyn označený na mapovom liste 2. vojenského mapovania z roku 1845. Tento mlyn stál povyše ústia Riečanky do Tajovského potoka. ÖStA - KA, Franziszeische Landesaufnahme, Section 39 - Colonne XXXII.
} 
Odtial'to postupovala komisia Pastierskou dolinou cestou popri Tajovskom potoku smerom na Králiky. ${ }^{39}$ Hranica viedla popri ceste, ktorá zároveň kopírovala tok Tajovského potoka tečúceho nal'avo od nej. Popri posledných dvoch domoch a záhradách tajovských robotníkov prišla komisia na miesto, kde do Tajovskej doliny zl'ava ústila dolina Mútne s rovnomenným potokom. Popri malom moste cez Tajovku k ceste vedúcej do doliny Mútne a d’alšiu záhradu na pravej strane cesty viedla hranica až k sútoku Tajovského a Farbeného potoka. Od tohto miesta, na ktorom stál dom v lokalite pod Studenuo, sa hranica definitívne odklonila od cesty na Králiky a pokračovala d'alej výlučne tokom Tajovského potoka.

Ned'aleko uvedeného miesta na vyčnievajúcej skale na l'avej strane potoka nechala komisia vytesat' d'alší hraničný znak v podobe mestského štítu. Ďalej komisia prešla popri podzemnej vyvieračke Tajovského potoka a pokračovala jeho suchým korytom. Niekde v týchto miestach obhliadka $v$ danom dni skončila. Nasledujúceho dňa (3. augusta) postupovala komisia nahor suchým korytom potoka okolo miesta, kde sa otvárala napravo dolina pod Malachouszkou až k lokalite pod Sztrminu, ned'aleko ktorej sprava ústil do Tajovského potoka menší potôčik Sztudenecz (Studený potok). Na tomto úseku sa blízko seba nachádzali dva vytesané hraničné znaky mesta. Prvý z nich bol vytesaný do skaly vyčnievajúcej z úbočia nad potokom (obr. 1). ${ }^{40}$ Druhý nechala komisia vytesat' do vel'kého kameňa trčiaceho z brehu potoka (obr. 2). ${ }^{41}$

Od sútoku Studeného a Tajovského potoka sa hranica tiahla nahor korytom hraničného potoka cez dolinu nazývanú do Studenca (valle nomen do Sztudenjecz). Touto dolinou sa komisia dostala na miesto nazývané pod Kováčovou lúkou (ad Localitatem pod Kovacsowu Luku), kde sa nachádzal aj malý most cez potok. Na kameň poniže tohto mosta nechala komisia vytesat' hraničný znak so štítom mesta. Ďalej kopírujúc hranicu prešla komisia popri mieste, kde sa do Tajovského potoka sprava vlieval nepatrný potôčik až ku vodopádu (antiquae Cataractae), nad ktorým sa nachádzala Kováčova lúka (Kovacsova Luka). Na nej sa komisia rozhodla prenocovat' a v obhliadke pokračovat' na d'alší deň.

\footnotetext{
${ }^{39}$ Na mape banskobystrického chotára od Jána Nepomuka Liptáka z roku 1859 je ako Pastierska dolina (Thal Pasztierszka) označená susedná dolina vedúca od Tajova smerom na Kordíky. ŠA BB, Zbierka máp a plánov, ev. č. 2629.

${ }^{40} \mathrm{Z}$ formulácie (saxo Civitatis scutum incisum est) nie je zrejmé či tento hraničný znak už komisia našla, alebo ho nechala vytesat'. Každopádne uvedený hraničný znak sa podarilo identifikovat' a zdokumentovat' priamo v teréne.

41 Uvedený hraničný kameň zdokumentoval pán Ján Vicen. Pri opakovanej obhliadke miesta sa zatial' nepodarilo tento hraničný kameň opätovne dohl'adat'. Je pravdepodobné, že mohlo dôjst' k jeho zaneseniu počas pravidelne sa opakujúceho vybrežovania divo tečúceho potoka, ku ktorému dochádza hlavne v období jarných mesiacov.
} 
Nasledujúci deň (4. augusta) obhliadka pokračovala cez miesto pod Scharianczovou Szkalou, d'alej hraničným potokom smerom k hlavnému hrebeňu Kremnických vrchov. Tu hranica viedla popri dvoch menších potôčikoch, ktoré sa zl'ava vlievali do hraničného toku až ku dvom prameňom a banskej štôlni (Cuniculo fodinae). Od tohto miesta hranica vystupovala po strmom úbočí priamo na hlavný hrebeň Kremnických vrchov. Na tomto úseku nechala komisia vytesat' jeden hraničný znak rodiny Radvanských a niekol'ko hraničných znakov mesta Banská Bystrica. Na jednom z nich, nachádzajúcom sa tesne pod hrebeňom, nechali vytesat' aj letopočet 1820 (saxo scutum Civitatis et Annum 1820 incid curavimus).

Reambulácia hraničného úseku definitívne skončila až 19. septembra na mieste trojhraničného bodu, ktorý predstavoval vrchol kopca Kremnická skala (Sarjancowa, Schranzenstein). ${ }^{42}$ Ešte predtým tu komisia nechala postavit' hraničnú kopu z kameňov a zeminy s hraničným kameňom označeným $\mathrm{z}$ východnej strany písmenami CN a letopočtom 1820 a zo západnej strany písmenami DR. Písmená CN v tomto prípade označovali mesto Banská Bystrica (Civitas Neosolium) a písmená DR označovali panstvo Radvaň, resp. Radvanských (Dominium Radvan). Hraničný znak Kremnice sa na tomto mieste vôbec nespomínal. Komisia mu nevenovala bližšiu pozornost' zrejme preto, že to vzhl'adom na reambuláciu tohto úseku hranice nepovažovala za potrebné. ${ }^{43} \mathrm{~V}$ súčasnosti je možné na tomto mieste identifikovat' dva kamene označené hraničnými znakmi. Na prvom je vytesaný erb Banskej Bystrice vo svojej redukovanej podobe a vedl'a neho písmená CN. Na rovnakej strane hore sa nachádza letopočet 1820 (obr. 3). Na kremnickej strane toho istého hraničného kameňa je vytesaný erb mesta Kremnice v podobe katarínskeho polokolesa doplnený písmenom $\mathrm{C}$ nad ním. Na vrchu hraničného kameňa je vytesaný nie celkom pravidelný rovnoramenný krížik. ${ }^{44}$ Ned'aleko tohto hraničného kameňa sa nachádza druhý kameň s vytesanými literami DR (obr. 4).V ich

\footnotetext{
${ }^{42}$ Názov Sarjancowa, resp. Schranzenstein, v mape Sarjancowa skala, zrejme označoval výrazné skalné bralá nachádzajúce sa medzi kótami Suchá hora (1 231 m n. m.) a Kremnická skala (1 $212 \mathrm{~m}$ n. m.). Trojhraničný bod sa v skutočnosti nachádzal na ned'alekom vrchole Kremnickej skaly. Svedčia o tom zachované pozostatky hraničnej kopy a hraničné kamene so znakmi Banskej Bystrice, Radvane (Radvanských) a Kremnice.

${ }^{43}$ Hraničný znak Kremnice, označený štítom (erbom) mesta v tvare katarínskeho polokolesa a doplnený majuskulným písmenom $\mathrm{C}$ nad ním, sa spomína až na začiatku opisu nasledujúceho hraničného úseku, na ktorom mesto Banská Bystrica susedilo s mestom Kremnica.

${ }^{44}$ Hraničný kameň je pamiatkovo chránený a evidovaný Pamiatkovým úradom SR v Registri nehnutel’ných národných kultúrnych pamiatok pod číslom ÚZPF 3421/1 v rámci katastrálneho územia Tajov. Podl'a stručného popisu v evidencii sa nachádza medzi Banskou Bystricou a Kremnicou. Ako doba jeho vzniku je uvedený rok 1820. Stavebno-technický stav je zhodnotený ako narušený. Za kultúrnu pamiatku bol hraničný kameň vyhlásený 12 . 2. 1982 rozhodnutím R-ONV B. Bystrica 23/82.
} 
blízkosti je viacero menších aj väčších kameňov, ktoré sú zaiste pozostatkami spomínanej hraničnej kopy, ktorá tu v minulosti stála.

Priebeh celého úseku spoločnej hranice Banskej Bystrice a panstva Radvanských od sútoku Udurny s Hronom až na hrebeň Kremnických vrchov priamo na trojhraničnom mieste potvrdili traja stoliční úradníci. Z hl'adiska úradníckej hierarchie najvýznamnejším spomedzi nich bol ustanovený podžupan (Surrogatus Vice-Comes) Zvolenskej stolice L'udovít Benický (Ludovicus Beniczky de Eadem et Mitsinye, 1777 - 1837).45 Ďalšími dvoma boli podslúžny Zvolenskej stolice Wolfgang Rakovský (Wolffgangus Rakovszky) ${ }^{46}$ a riadny prísažný prísediaci Zvolenskej stolice Jozef Strakonický (Iosephus Sztrakoniczky). ${ }^{47}$

$\mathrm{V}$ textovej časti Metales sa na tomto úseku hraníc nachádza zmienka o 20-tich vytesaných hraničných znakoch. Len dva spomedzi nich predstavovali symboly panstva Radvanských. Všetky ostatné boli hraničné znaky mesta Banská Bystrica.

Na mape príslušného hraničného úseku možno zaznamenat' existenciu 19-tich hraničných znakov na 17-tich miestach. Tri hraničné znaky boli zakreslené na trojhraničnom bode Kremnická skala. Radvanský hraničný znak bol zakreslený iba na tomto jedinom mieste. V porovnaní s realitou tu možno vidiet' znak tvorený písmenami DR doplnený symbolom obrneného ramena l'udskej ruky so zvierajúcou vetvičkou, ktorý bol odvodený z erbu Radvanských. Banskobystrický hraničný znak je tu znázornený iba prostredníctvom písmen $\mathrm{CN}$ a letopočtu 1820, na rozdiel od ostatných lokalít bez vyobrazenia erbu. Navyše je v mape zakreslený aj kremnický hraničný znak, ktorý sa v písomnom opise tohto úseku vôbec nespomína.

\footnotetext{
${ }^{45}$ L’udovít (I.) Benický bol príslušníkom mičinskej vetvy (sídlil v kaštieli v Dolnej Mičinej) turčianskeho šlachtického rodu pôvodom z Beníc. V roku 1808 bol menovaný prvým podnotárom a nasledujúceho roku (1809) sa stal riadnym notárom Zvolenskej stolice. Podl'a Tomáša Januru zastával tento post až do roku 1827, kedy bol zvolený za zastupujúceho (druhého) podžupana. Tento úrad následne zastával do roku 1832. Neskôr získal čestný titul cisársko-král'ovského radcu, pričom pôsobil tiež ako radca Uhorskej komory a dvorský referent pre baníctvo. Podl'a: JANURA, Úradníci Zvolenskej stolice v rokoch 1790 - 1848, s. 122; resp. JANURA - FILLOVÁ - ŠIMKOVIC, Vidiecke šlachtické sídla v Zvolenskej stolici, s. 72.

46 Tomáš Janura predpokladá, že Wolfgang Rakovský bol synom významného člena rodu Alexa Rakovského (1724 - 1792), ktorý dlhé roky pôsobil ako riadny (hlavný) notár Zvolenskej stolice a v rokoch 1778 - 1785 a 1790 - 1792 aj ako riadny (prvý) podžupan Zvolenskej stolice. Wolfganga pritom uvádza ako podslúžneho dolného okresu, ale aj ako slúžneho horného okresu. JANURA, Úradníci Zvolenskej stolice v rokoch 1790 - 1848, s. 123. ${ }^{47}$ Príslušníci pôvodom českého rodu Strakonických sa vo Zvolenskej stolici usadili v 18. storočí. Za Márie Terézie bol v roku 1741 člen rodu Andrej Strakonický povýšený do šlachtického stavu. Jeho syn Ladislav získal na konci 18. storočia kaštiel' v Dúbravici. JANURA FILLOVÁ - ŠIMKOVIC, Vidiecke šl'achtické sídla v Zvolenskej stolici, s. 74 a 78.
} 
Záverom možno zhrnút', že prvé hraničné znaky na tomto úseku hranice sa nachádzali v blízkosti cesty do Skubína, na mieste kde sa hranica vzdialila od prvého hraničného toku Udurny. Na úseku, kde hraničná línia viedla $v$ tesnej blízkosti, alebo priamo korytom Tajovského potoka, sa hraničné znaky umiestňovali skôr výnimočne. Naopak, najviac hraničných znakov bolo vytvorených v pramennej oblasti Tajovského potoka pod Kremnickou skalou. Hraničnú líniu tu nebolo možné viest' prostredníctvom výrazných prirodzených bariér a preto orientácia v teréne bola st’ažená. Práve preto tu bolo potrebné umiestnit' najviac hraničných znakov.

Textová a mapová čast' banskobystrického Metales je neocenitel'nou pomôckou pri presnom vymedzení historických hraníc mestského chotára. Podrobné štúdium tohto materiálu v kombinácii s d'alším archívnym a terénnym výskumom môže priniest' zaujímavé objavy a zistenia týkajúce sa lokalizovania a určenia vlastníkov pozemkov a stavebných objektov ležiacich pri hraničnej línii, poznania dobovej toponymie, procesu formovania hraníc, ale aj vytvárania a ochrany hraničných medzníkov. Ide o najdôležitejší dokument umožňujúci lokalizáciu hraničných medzníkov umiestnených na hraniciach mesta. Zdokumentovanie viacerých hraničných kôp, hraničných kameňov a znakov pomocou tohto dokumentu in situ je toho jasným dôkazom. 
Príloha č. 1. Menný zoznam účastníkov reambulácie juhozápadného úseku mestských hraníc spoločných so susedným teritóriom rodiny Radvanských

Za mesto Banská Bystrica (43 osôb):

Jozef Kellner, mestský radný (senator)

Ján Fluck, mestský radný (senator)

Jozef Rottermund,* mestský radný (senator)

Michal Rarus, mestský radný (senator)

Gabriel Urbáni (Urbányi), mestský radný (senator)

Ján Sumrák (Szumrak), podnotár (vice-notario)

Štefan Husák (Huszágh), fiškál (surrogato fiscali)

Maximilián Ondrejkovič (Ondrejkovits), tribún l’udu (tribuno plebis)

Ignác Waisz, účtovník (rationum exactore)

Ignác Palkovics, pokladník a výberca vojnových kontribúcii (cassae bellicae perceptore)

Štefan Pet'ko (Pettyko), prvý pisár (primario cancellista, et regestratore)

Michal Lassovszky, člen volenej obce a desiatnik (electae communitatis commembro, et decimatore)

Andrej Czilchert, mešt'an a člen volenej obce (civis, et electae communitatis commembro)

Jakub Rhaner, mešt’an a člen volenej obce (civis, et electae communitatis commembro)

Karol Invitty, mešt’an a člen volenej obce (civis, et electae communitatis commembro)

Michal Palesch, mešt'an a člen volenej obce (civis, et electae communitatis commembro)

Michal Kellner, mešt’an (civis)

Samuel Roznauer, mešt'an (civis) a jeho 11-ročný syn L'udovít

Benjamín Reinlander, mešt’an (civis)

Michal Fischer, mešt'an (civis)

Samuel Libay, mešt’an (civis) a jeho 10-ročný syn Gustáv

Daniel Kellner, 15-ročný syn mešt’ana (filius civis)

L'udovít Kolbenheyer, 15-ročný syn mešt'ana (filius civis)

Karol Czilchert, 13-ročný syn mešt'ana (filius civis)

Vendelín Rottermund, 16-ročný syn mešt’ana (filius civis)

Jozef Vozár (Wozár), 18-ročný syn mešt’ana (filius civis)

Ján Urbáni (Urbány), mešt’an (civis)

Pavol Beloczy, mešt’an (civis)

Štefan Šándor (Sándory), mešt’an (civis)

Pavol Ruttkay, mešt'an (civis)

Jakub Baicsy, mešt'an (civis) 
Daniel Albrecht, mešt'an (civis)

Pavol Messatoris, mešt'an (civis)

Jozef Ondrey, mešt'an (civis)

Michal Steffek, mešt'an (civis) a jeho 16-ročný syn L'udovít

Daniel Čečetka (Csecsetka), mešt'an (civis)

Pavol Flora, mešt'an (civis)

Jozef Spevak, mešt’an (civis)

Juraj Pecznik, mešt'an (civis)

Matej Stogl, predák murárov (murariorum pallirio)

Za mesto Banská Bystrica z dediny Harmanec (12 osôb):

Michal Baláž st. (Seniore Balás), robotník mesta (operarius civitatis)

Michal Baláž ml. (Iuniore Balás), robotník mesta (operarius civitatis)

Michal Waisz st., robotník mesta (operarius civitatis)

Jozef Babiak, robotník mesta (operarius civitatis)

Andrej Daubner, robotník mesta (operarius civitatis)

Ján Gregor, robotník mesta (operarius civitatis)

Michal Waisz ml. (Iuniore Waisz), robotník mesta (operarius civitatis)

Ján Baláž (Balás), robotník mesta (operarius civitatis)

Andrej Waisz, robotník mesta (operarius civitatis)

Jozef Paraczka, robotník mesta (operarius civitatis)

Jozef Lichner, robotník mesta (operarius civitatis)

Andrej Schmidt, robotník mesta (operarius civitatis)

Z iných dedín v chotári Banskej Bystrice (5 osôb):

Juraj Styk (Stik) z Majera podliehajúci jurisdikcii komory

Jakub Jurák (Iurak) z Kostiviarskej podliehajúci jurisdikcii komory

Andrej Otiepka (Otyiepka) z Kostiviarskej podliehajúci jurisdikcii mesta

Michal Slivka (Sliuka) z Kostiviarskej podliehajúci jurisdikcii mesta

Matej Droba z Jakuba podliehajúci jurisdikcii mesta

Za Banská komoru v Banskej Bystrici (5 osôb):

Ján Wissney (Wissnyei), komorský fiškál (Camerae R. Neosoliensis fiscali)

Ján Kolinazy, provízor (provisore)

Jozef Dekret (Decret), lesmajster (sylvarum magistro)

Florián Than, pomocník fiškála (fiscali adjuncto)

Ján Obereigner, lesný praktikant (sylvanali practicante)

Za rodinu Radvanských (3 osoby):

Anton Radvanský (Radvanszky de Radvan, et Sajó-kaza), zastupujúci (druhý) podžupan Zvolenskej stolice (substitutus vice-comes)

Karol Radvanský (Radvanszky de Radvan) 
František Banko, zástupca a provízor (provisore) Evy Prónay - vdovy po zosnulom král'ovskom radcovi Jánovi Radvanskom (Ioannis de Radvan et Sajokaza)

\section{Z mestečka Radvaň (31 osôb):}

Juraj Markovič (Markovits), notár mestečka (notario oppidi)

Ján Bečko (Becsko), obyvatel' mestečka (oppidanus)

Ján Chlpko, obyvatel' mestečka (oppidanus)

Daniel Kruspán, obyvatel' mestečka (oppidanus)

Michal Mráz, obyvatel' mestečka (oppidanus)

Andrej Solivajecz, obyvatel' mestečka (oppidanus)

Andrej Klincsok, obyvatel' mestečka (oppidanus)

Andrej Braczka, obyvatel' mestečka (oppidanus)

Samuel Riečanský (Rietsanszky), obyvatel' mestečka (oppidanus)

Ján Schlejmer, obyvatel' mestečka (oppidanus)

Andrej Settenreich, obyvatel' mestečka (oppidanus)

Andrej Dvorský (Dvorszky), obyvatel' mestečka (oppidanus)

Andrej Czemann, obyvatel' mestečka (oppidanus)

Andrej Markovič (Markovics), obyvatel' mestečka (oppidanus)

Samuel Markovič (Markovics), obyvatel' mestečka (oppidanus)

Nikola Arnus, obyvatel' mestečka (oppidanus)

Juraj Murgáts, obyvatel' mestečka (oppidanus)

Ján Luby, obyvatel' mestečka (oppidanus)

Ján Ondricsin, obyvatel' mestečka (oppidanus)

Andrej Chlpko, obyvatel' mestečka (oppidanus)

Samuel Riečanský ml. (Rjecsanszky juniore), obyvatel' mestečka (oppidanus)

Michal Mráz ml. (juniore), obyvatel' mestečka (oppidanus)

Daniel Schlejmer ml. (juniore), obyvatel' mestečka (oppidanus)

Ján Furdik, (ductor oppidi)

Andrej Markovič ml. (Markovics juniore) 15-ročný obyvatel' mestečka (oppidanus)

Samuel Furdik 14-ročný obyvatel' mestečka (oppidanus)

Pavol Besskó ml. (juniore), obyvatel' mestečka (oppidanus)

Ján Chlpko ml. (juniore), obyvatel' mestečka (oppidanus)

Ján Matrošovič ml. (Matrossovits juniore), obyvatel’ mestečka (oppidanus) Ján Braczka 15-ročný obyvatel' mestečka (oppidanus)

Daniel Mosko, lesník Radvanských (sylvanus Inclytae Familiae de Radvan)

Z dediny Skubín (12 osôb):

Ján Bukovský (Bukovszky), richtár (iudex)

Matej Szolivajecz

Juraj Ursini 


\section{Oto Tomeček}

Matej Kutzian,16-ročný chlapec

Ján Steffko, 14-ročný chlapec

Andrej Kollar

Ján Neczpalik

Matej Chmelko

Matej Semsely,

Juraj Arnus,

Ján Veszel,

Ján Handlovský (Handlouszky)

* Podl'a zoznamu radných, ktorý zostavil Emil Jurkovich bol v roku 1820 členom mestskej rady len Ján Rottermundt.

Príloha č. 2. Toponymá uvedené v textovej a mapovej časti Metales pri reambulácii juhozápadného úseku mestských hraníc spoločných so susedným teritóriom rodiny Radvanských

\begin{tabular}{|c|c|c|c|c|}
\hline $\begin{array}{l}\text { reambulácia } \\
1820 \text { (text) }\end{array}$ & $\begin{array}{l}\text { reambulácia } \\
1820 \text { (mapa) }\end{array}$ & $\begin{array}{l}\text { staršie } \\
\text { doklady }\end{array}$ & $\begin{array}{l}\text { súčasný } \\
\text { názov }\end{array}$ & $\begin{array}{l}\text { druh } \\
\text { toponyma }\end{array}$ \\
\hline Udurna & $X$ & Vdurna (1255) & \begin{tabular}{|l} 
Radvanský \\
potok
\end{tabular} & hydronymum \\
\hline Radvan & $X$ & $\begin{array}{l}\text { villa Raduana } \\
\text { (1263) }\end{array}$ & Radvaň & ojkonymum \\
\hline Körmöcske & $\mathrm{X}$ & $\begin{array}{l}\text { Keremchey } \\
\text { (1291) }\end{array}$ & Kremnička & ojkonymum \\
\hline Motičina & $\mathrm{X}$ & $\mathrm{X}$ & $\mathrm{X}$ & hydronymum \\
\hline Szkubin & $\mathrm{X}$ & Scubin (1538) & Skubín & ojkonymum \\
\hline Podlavitz & $\mathrm{X}$ & $\begin{array}{l}\text { Podlawycha } \\
\text { (1368) }\end{array}$ & Podlavice & ojkonymum \\
\hline Holje Huorky & $\mathrm{X}$ & $\begin{array}{l}\text { Hola hurka } \\
\text { (1547) }\end{array}$ & $\mathrm{X}$ & oronymum \\
\hline Tajouka & $\mathrm{X}$ & $\begin{array}{l}\text { Sevnice (1287), } \\
\text { Teya (1567) }\end{array}$ & \begin{tabular}{|l} 
Tajovský \\
potok
\end{tabular} & hydronymum \\
\hline vallis Hlboka & $\mathrm{X}$ & $\mathrm{X}$ & $\mathrm{X}$ & oronymum \\
\hline Tajova & $\begin{array}{l}\text { villa M: Caalis } \\
\text { Tajova }\end{array}$ & Tayowa (1516) & Tajov & ojkonymum \\
\hline Iabrikova & Iabrikova & $\begin{array}{l}\text { Jabrickowa } \\
\text { (1696) }\end{array}$ & Jabríková & ojkonymum \\
\hline Kordikiensis rivus & $\mathrm{X}$ & $\mathrm{X}$ & \begin{tabular}{|l|} 
Kordícky \\
potok
\end{tabular} & hydronymum \\
\hline vallis Pasztjerszka & $\mathrm{X}$ & $\mathrm{X}$ & $\mathrm{X}$ & oronymum \\
\hline Kralik & $\mathrm{X}$ & Kralyiki (1738) & Králiky & ojkonymum \\
\hline
\end{tabular}


Metales Banskej Bystrice z roku 1820 ...

\begin{tabular}{|c|c|c|c|c|}
\hline vallis do Mutnjho & Do Mutneho & $\mathrm{X}$ & Mútne & oronymum \\
\hline rivulus Mutno & $X$ & $X$ & $\begin{array}{l}\text { Mútňanský } \\
\text { potok }\end{array}$ & hydronymum \\
\hline vallis Farbenuo & Farbenuo & $X$ & $\begin{array}{l}\text { dolina Farbe- } \\
\text { ného potoka }\end{array}$ & $\begin{array}{l}\text { oronymum / } \\
\text { hydronymum }\end{array}$ \\
\hline pod Studenuo & $X$ & $X$ & $\mathrm{X}$ & $\begin{array}{l}\text { chotárny } \\
\text { názov }\end{array}$ \\
\hline $\begin{array}{l}\text { vallis pod Mala- } \\
\text { chouszkou }\end{array}$ & $X$ & $X$ & $\mathrm{X}$ & oronymum \\
\hline pod Sztrminu & Pod Strminu & $X$ & $\mathrm{X}$ & $\begin{array}{l}\text { chotárny } \\
\text { názov } \\
\end{array}$ \\
\hline $\begin{array}{l}\text { rivulus Sztude- } \\
\text { necz }\end{array}$ & Studenec & $X$ & $\begin{array}{l}\text { Studené / Stu- } \\
\text { dený potok }\end{array}$ & hydronymum \\
\hline $\begin{array}{l}\text { vallis do Sztuden- } \\
\text { jecz }\end{array}$ & Do Studenjec & $X$ & Studenec & oronymum \\
\hline $\begin{array}{l}\text { pod Kovacsowu } \\
\text { Luku }\end{array}$ & \begin{tabular}{|l|} 
Pod Ko- \\
vácsovu Luku \\
\end{tabular} & $X$ & $\mathrm{X}$ & $\begin{array}{l}\text { chotárny } \\
\text { názov }\end{array}$ \\
\hline Kovacsova Luka & $\mathrm{X}$ & $X$ & $\mathrm{X}$ & $\begin{array}{l}\text { chotárny } \\
\text { názov }\end{array}$ \\
\hline $\begin{array}{l}\text { pod Scharianczo- } \\
\text { vou Szkalou }\end{array}$ & $X$ & $X$ & $\mathrm{X}$ & $\begin{array}{l}\text { chotárny } \\
\text { názov }\end{array}$ \\
\hline $\begin{array}{l}\text { Sarjankova/ } \\
\text { Sarjancowa }\end{array}$ & $\begin{array}{l}\text { Sarjancowa } \\
\text { skala }\end{array}$ & $\begin{array}{l}\text { Schrantzenstein } \\
(1574)\end{array}$ & $\begin{array}{l}\text { Skalka resp. } \\
\text { Kremnická } \\
\text { skala }\end{array}$ & oronymum \\
\hline
\end{tabular}




\section{Oto Tomeček}

Obr. 1. Hraničný znak Banskej Bystrice na skalnom brale v doline Tajovského potoka, foto: Oto Tomeček

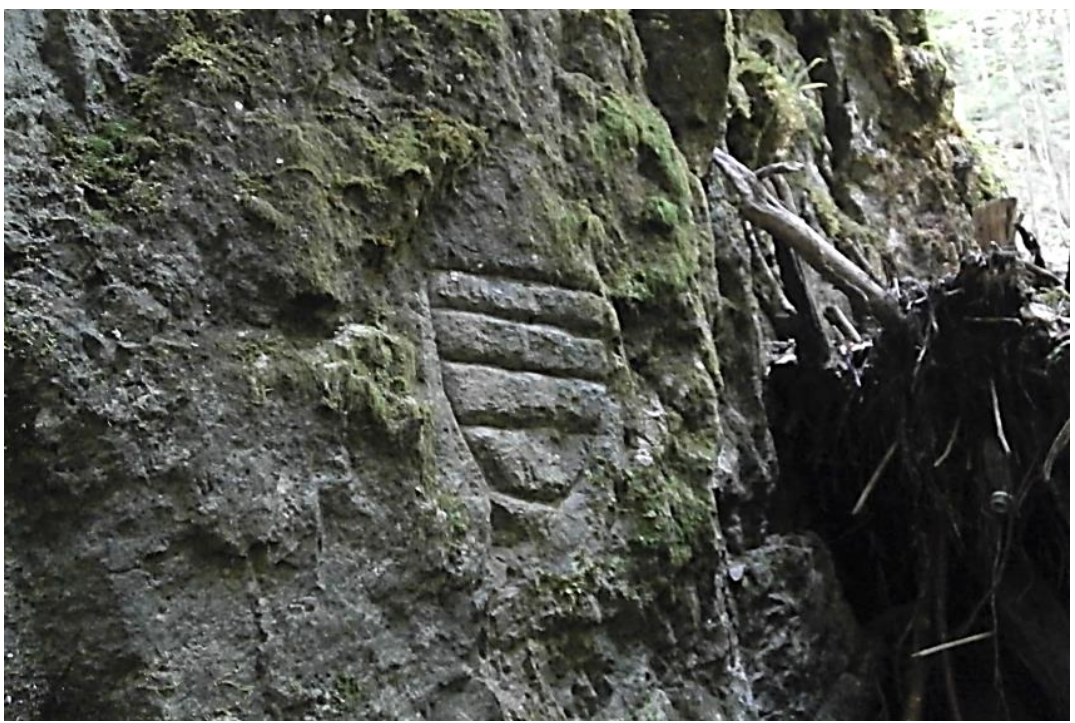

Obr. 2. Hraničný znak Banskej Bystrice na kameni vyčnievajúcom z brehu Tajovského potoka, foto: Ján Vicen

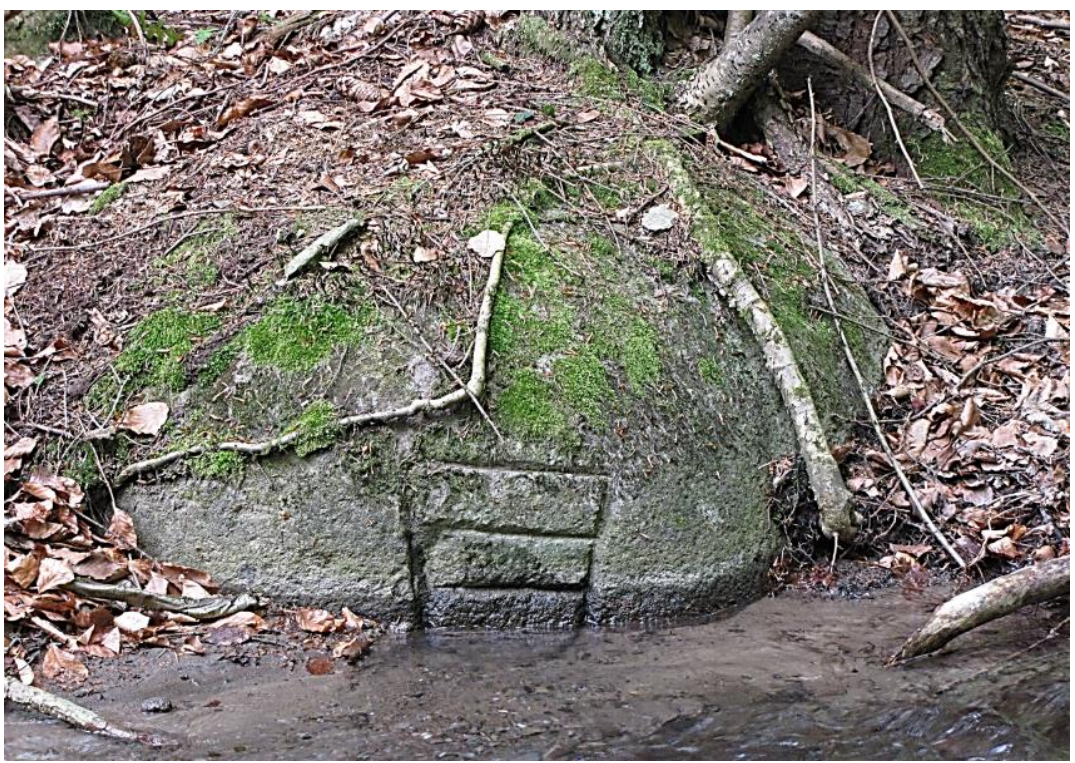


Metales Banskej Bystrice z roku 1820 ...

Obr. 3. Hraničný znak Banskej Bystrice na kameni umiestnenom na trojhraničnom mieste Kremnická skala, foto: Oto Tomeček

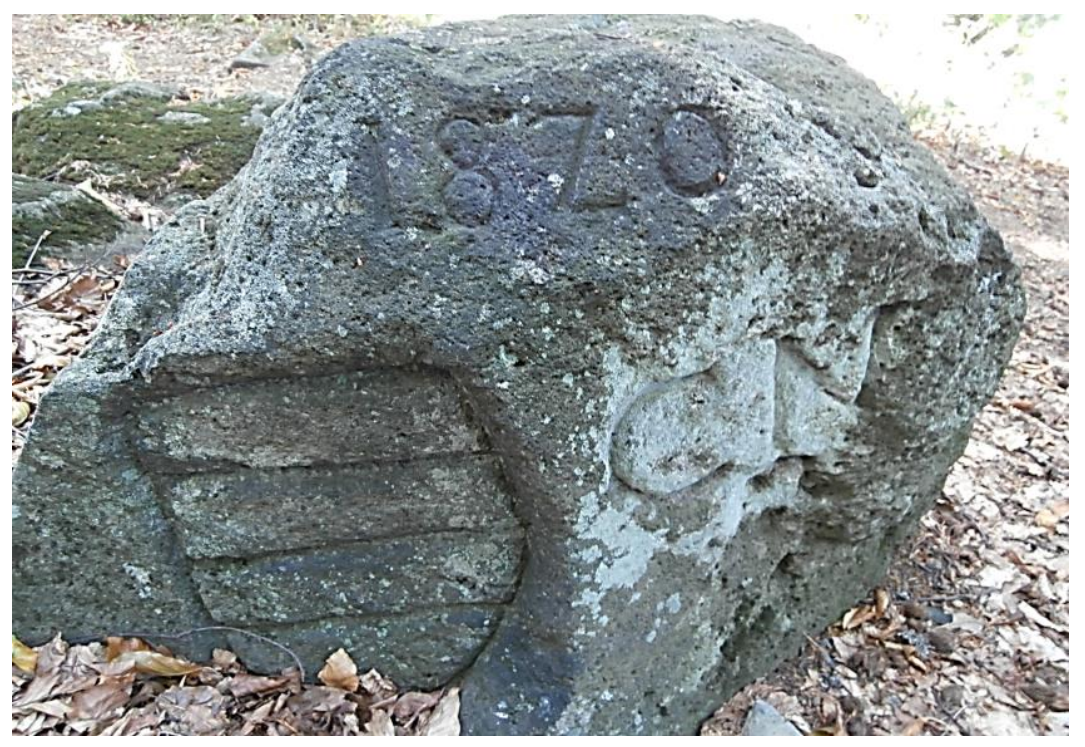

Obr. 4. Hraničný znak Radvanských na kameni umiestnenom na trojhraničnom mieste Kremnická skala, foto: Oto Tomeček

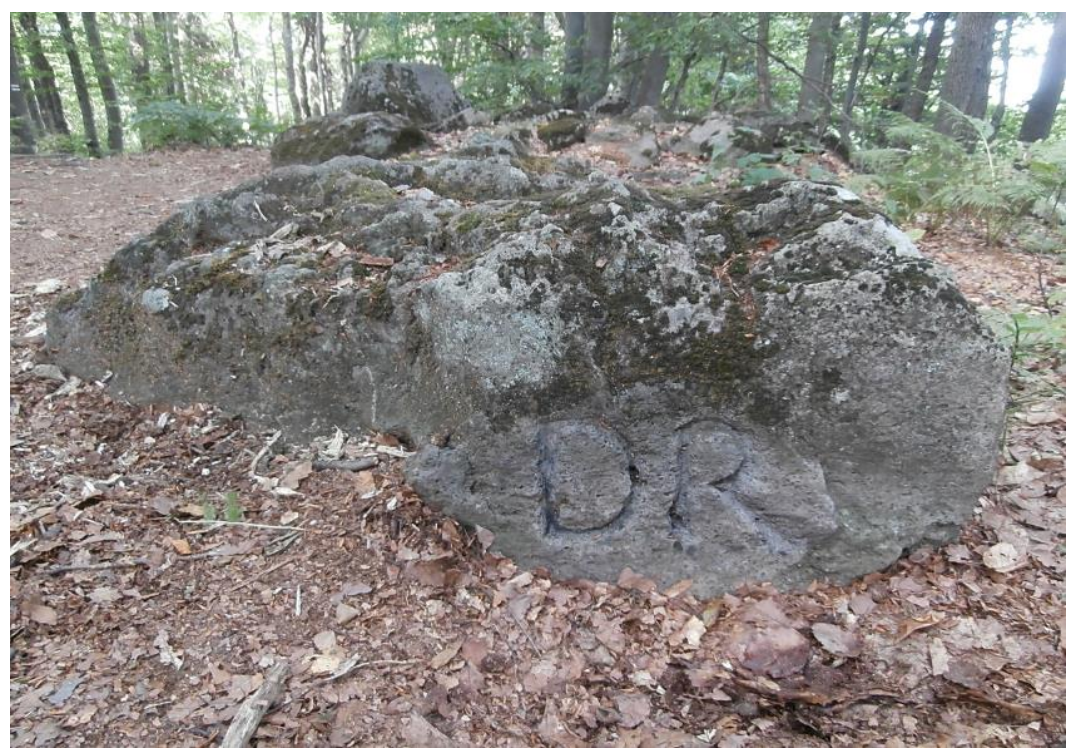

